\title{
FINE SPECIFICITY AND GENETIC RESTRICTION OF T CELL CLONES SPECIFIC FOR MOUSE HEPATITIS VIRUS, STRAIN JHM
}

\author{
Jerold G. Woodward, John O. Fleming, Glenn K. Matsushima, \\ Jeffrey A. Frelinger, and Stephen A. Stohlman \\ University of Southern California, School of Medicine \\ 2025 Zonal Avenue, Los Angeles, CA 90033
}

\section{INTRODUCTION}

Mouse hepatitis viruses are members of the coronavirus group of animal viruses. Although named for their propensity to induce acute hepatitis in animals stressed by a variety of conditions, it has become clear that as a group they possess the ability to cause a diverse group of diseases in their natural host (Wege, et al, 1982). One strain of MHV, named JHM virus (JHMV), was isolated from mice found to have demyelinated lesions of the central nervous system (Bailey, et al, 1949). More recently it has been found that JHMV is not only capable of causing acute encephalomyelitis with demyelination but also chronic demyelination probably due to the establishment of a latent infection of oligodendroglia, the cells of myelin within the central nervous system (Herndon, et al, 1975; Stohlman and Weiner, 1981).

In our attempts to understand the role of the host in the establishment and maintance of latent JHMV infection and chronic demyelination we first examined a panel of inbred mice and found that only one, SJL, of the 13 strains tested was resistant to JHMV infection (Stohlman and Frelinger, 1978). Backcross analysis using two $\mathrm{H}-2$ identical strains, SJL and B10.S, indicated that two genes were required for resistance. One of these genes is dominant, designated Rhv-1, and one is recessive, designated $\mathrm{Rhv}-2$. This analysis using two strains of mice identical at the major histocompatibility complex is compelling evidence that $\mathrm{H}-2$ linked genes are not involved in conferring resistance to JHMV. Inspite of the lack of $\mathrm{H}-2$ linkage, resistance to fatal disease in $\mathrm{SJL}$ mice is abolished by $\mathrm{X}$-irradiation, suggesting that the cell-mediated immune system plays a crucial role in protection (Stohlman, unpublished data). 
In susceptible mice, which in opposition to SJL, become latently infected following survival from the acute encephalomyelitis, we have also found suggestive evidence that cell-mediated immunity plays a crucial role in protection from acute disease. First, we have found, as have others ( $M$. Happel, personal communication), that anti-viral antibody is incapable of protecting mice from acute JHMV encephalomyelitis. Second, we found that mice immunized by intraperitoneal injection with JHMV were refractory to intracranial infection with JHMV by 4 days post immunization. Additional evidence has accumulated that antibody is capable of interacting with the viral proteins on the surface of infected cells resulting in the cessation of production of infectious virus (Stohlman and Weiner, 1978). Virus persists in these cells even after the removal of the anti-viral antibody, suggesting that antibody is not effective in protection and in fact it may be a very detrimental host response leading to the establishment of latently infected cells in the CNS.

In order to better characterize the mechanisms of host resistance to JHMV infection we have produced $T$ cell clones reactive to JHMV antigens. In this paper, we describe the detailed analysis of four $T$ cell clones in terms of antigen specificity, genetic restriction and capacity to function in the delayed type hypersensitivity response to JHMV antigen.

\section{MATERIALS AND METHODS}

Mice: The C57BL/6 (B6) mice immunized to obtain the $\mathrm{T}$ cell clones were obtained from Jackson Laboratories, Bar Harbor, MA, at 6 weeks of age and used immediately. All other mice used in this study were bred and housed in the Immunogenetics mouse colony, University of Southern California, School of Medicine.

Virus: The plaque purified small plaque variant of the neurotropic JHM strain of MHV was used throughout. The isolation and propagation of this virus, designated JHMV-DS, have been previously described (Stohlman, et al, 1982). The immunogen for these studies was prepared by infecting $5 \times 150 \mathrm{~cm}$ tissue culture plates of DBT cells with JHMV-DS at an MOI of approximately 0.1 . At complete viral induced fusion (14-16 hrs post infection) the cell sheets were first washed $2 x$ with sterile PBS and then the cells were removed from the plates by scraping. The cells from each plate were placed in $5 \mathrm{ml}$ of PBS, sonicated, and the resulting suspension clarified by centrifugation at $500 \mathrm{x}$ g for $10 \mathrm{~min}$. The clarified sonicate was stored at $-70^{\circ} \mathrm{C}$. Uninfected monolayers of DBT cells processed in a like manner served as control antigen. Infected cell lysates were prepared from two additional viruses, MHV-A59 and MHV-2. The lysates were prepared as described above except that the MOI used was 1.0. The lysates were prepared from MHV-A59 cells at $8 \mathrm{hrs}$ post infection and from MHV-2 infected cells at 24 hrs post infection.

Purified JHMV was prepared as previously described (Lai and Stohlman, 1978). Briefly, supernatant fluids from infected cultures were 
clarified by centrifugation at $10,000 \times \mathrm{g}$ for $30 \mathrm{~min}$. The virus was pelleted through $20 \%$ sucrose by centrifugation for $2.5 \mathrm{hrs}$ at 27,000 RPM in an Beckman SW 28 rotor, resuspended, and banded by centrifugation on a $20-42 \%$ sucrose gradient at 40,000 RPM for 2 hrs.

Isolation of $\mathrm{T}$ cell clones: $\mathrm{B} 6$ mice were immunized in the hind footpads with JHMV antigen in Freund's complete adjuvant and 8 days later, their draining popliteal lymph nodes (DLN) were removed and teased into a single cell suspension. In early experiments, the proliferative capacity of these cells was determined by culturing $1 \times 10^{5}$ DLN cells in microtiter plate wells along with varying concentrations of JHMV or ${ }_{3}$ control antigen. Cell proliferation was determined by adding 1 $\mathrm{uCi}$ of ${ }^{3} \mathrm{H}$-thymidine, specific activity $2 \mathrm{Ci}$ per $\mathrm{mM}$ (New England Nuclear, Boston, Mass.), to each well 24 hrs prior to harvest. Cells were collected onto glass fiber filters, rinsed, dried and counted in a liquid scintillation counter. The medium used for all experiments was RPMI 1640 supplemented with, $100 \mathrm{units} / \mathrm{ml}$ pencillin, $50 \mathrm{ug} / \mathrm{ml}$ streptomycin, mM glutamine, $5 \times 10^{-5}$ M 2-mercaptoethanol and $10 \%$ fetal calf serum.

DLN cells destined for cloning were cultured in 24 well Linbro plates at a density of $3 \times 10^{6} \mathrm{DLN}$ cells/well along with a dilution of JHMV antigen that gave optimum proliferation in the microplate assay, usually 1:100. After 4 days, blast cells were ${ }_{5}$ harvested, washed, and re-seeded in 24 well plates at a density of $1 \times 10^{5}$ cells/well containing 2 $\times 10^{6}$ irradiated (2000rads) syngenic spleen cells, and the optimum dilution of JHMV antigen.

After 4 additional days the $T$ cells from this secondary stimulation were cloned at limiting dilution in 96 well plates in media containing $4 \mathrm{x}$ $10^{5}$ cells/well irradiated syngenic spleen cells, 5\% semi-purified mouse Con A supernatant as a source of interleukin-2, and JHMV antigen. After 4 days at $37^{\circ} \mathrm{C}$, each well received 50 ul of fresh medium containing the above additives. Colonies became visible after 8 days and were harvested after 10 days with a pasteur pipet. Cell clones were expanded in media containing the same additives and frozen in liquid nitrogen awaiting characterization. Clones $4 \mathrm{~B} 10$ and $4 \mathrm{G} 4$ were derived from a cloning plate that received 1 cell/well and had 13 wells with positive growth, or a cloning efficiency of $13.5 \%$. Clones $3 \mathrm{~B} 10$ and $3 \mathrm{C} 4$ were derived from a plate that received 0.5 cells/well and had a 6 wells with positive growth or a cloning efficiency of $12.5 \%$. All clones were recloned under the same conditions and colonies were taken from plates that had less than $33 \%$ positive wells.

In Vitro Proliferation Assay of $T$ cell clones: $T$ cell clones were seeded into 96 well microplates at a density of $2 \times 10^{4} \mathrm{~T}$ cells/well and cultured in the presence or absence of irradiated spleen cells $(4 \mathrm{x}$ $10 \%$ well) from various mouse strains and JHMV, MHV-2, MHV-A59 or Gontrol antigen. Cultures were pulsed on day 2 with $1 \mathrm{uCi}$ of ${ }^{3} \mathrm{H}$-thymidine and harvested on day 3 as described above. 
Delayed type Hypersensitivity Response: Normal unimmunized mice from various strains were injected in both hind footpads with $2 \times 10^{5} \mathrm{~T}$ cell clones and either control antigen (left foot) or JHMV antigen (right foot) in a total volume of $20 \mathrm{ul}$. Footpad thickness was measured with calipers 24,48 or 96 hours after injection. The data is expressed as the mean difference in footpad thickness (right - left) for groups of at least 4 mice \pm standard error of the mean.

Inhibition of Proliferation by Monoclonal Antibodies: The prolif erative response to JHMV was carried out as described above except that the wells received an additional $0.05 \mathrm{ml}$ of medium containing the monoclonal antibody supernatants. The derivation and characterization of the JHMV-specific monoclonal antibodies has been previously described (Fleming, et al, 1983). Each monoclonal antibody was used at a final dilution of $1 / 32$. The cultures were pulsed with ${ }^{3} \mathrm{H}$-thymidine on day 2 and harvested on day 3 as described above.

\section{RESULTS}

Isolation of JHMV-Specific T Cell Clones: In order to determine the optimum conditions for the cloning of JHMV specific $\mathrm{T}$ cells, a series of preliminary experiments were conducted using DLN cells from JHMV immunized mice. Initially, mice were immunized in the hind footpads with JHMV antigen in Freund's complete adjuvant and their DLN cells tested for proliferation eight days later. The data in Table 1 show the response of DLN cells to a lysate of JHMV infected cells as compared to a lysate of uninfected cells (control antigen). Although there is some response over background to the control antigen, the response to JHMV antigen is almost an order of magnitude greater. In this experiment, a 1:800 dilution of antigen gave the maximal response, therefore we used this dilution for the subsequent expansion and cloning of JHMV specific $T$ cells.

Table 1

PROLIFERATION OF DLN CELLS FROM MICE IMMUNIZED WITH JHM VIRUS ${ }^{1}$

\begin{tabular}{|c|c|c|c|c|}
\hline $\begin{array}{c}\text { Antigen } \\
\text { Added to Culture }\end{array}$ & Dilution & 48 & $\begin{array}{c}\text { Culture } \\
72 \\
\end{array}$ & 96 \\
\hline $\begin{array}{l}\text { None } \\
\text { Control }^{3} \\
\text { JHM }\end{array}$ & $\begin{array}{l}-1-- \\
1 / 200 \\
1 / 800 \\
1 / 200 \\
1 / 800\end{array}$ & $\begin{array}{r}3,600 \\
8,100 \\
9,200 \\
30,000 \\
93,000\end{array}$ & $\begin{array}{r}4,100 \\
13,600 \\
17,200 \\
70,300 \\
139,500\end{array}$ & $\begin{array}{r}4,200 \\
11,300 \\
15,800 \\
22,400 \\
90,400\end{array}$ \\
\hline
\end{tabular}

1. $\mathrm{C} 57 \mathrm{BL} / 6$ mice were immunized 8 days previously with lysate of JHM virus infected cells in Freunds complete adjuvant.

2. Incorporation of ${ }^{3} \mathrm{H}$-thymidine added $24 \mathrm{~h}$ prior to harvest. Results represent mean CPM of triplicate wells.

3. Control antigens represent whole cell lysate from uninfected DBT cells. 
To establish the JHMV-specific T cell clones, DLN cultures were re-stimulated once with a 1:800 dilution of JHMV antigen and fresh antigen presenting cells (APC), then cloned at limiting dilution with antigen, APC, and interleukin-2, as described in Materials and Methods. Four of the fourteen clones established by this procedure were chosen for initial characterization.

The presence of Thy -1 and Ly alloantigens on the surface of all four JHMV-specific $\mathrm{T}$ cell clones was determined an antibody and complement mediated microcytotoxicity assay. All clones were positive for Thy -1 as well as the Lyl marker. The clones were negative for the Ly 2,3 markers (data not shown). This phenotype is characteristic for the $\mathrm{T}$ helper subset of $\mathrm{T}$ cells whereas the $\mathrm{Lyl}^{-}, 2,3^{+}$phenotype serves to distinguish the cytotoxic $T$ cell subset (Swain, et al, 1981).

In vitro Genetic Restriction: One of the common characteristics of $\mathrm{Ly}^{+}$helper $\mathrm{T}$ cells is that they recognize antigen only in association with I region gene products on the surface of the antigen presenting cells (APC) (Yano, et al, 1977). The Ia antigens involved in this recognition are encoded by 2 gene loci, which code for the subunits that make up the I-A and I-E molecules respectively. The Ia antigens show considerable polymorphism, and as shown in Table 2, there are 8 commonly used inbred strains of mice defining different $\mathrm{H}-2$ haplotypes. We also used 3 recombinant strains, and a mouse strain derived from B6 with a mutation in the I-Ap chain, B6CH-2 12 .

Table 2

H-2 Haplotypes of Inbred Strains

\begin{tabular}{|c|c|c|c|c|}
\hline \multirow[b]{2}{*}{ Strain } & \multirow[b]{2}{*}{$\mathrm{K}$} & \multicolumn{2}{|c|}{ H-2 Subregion } & \multirow[b]{2}{*}{$\underline{D}$} \\
\hline & & $\mathrm{I}-\mathrm{A}$ & $\mathrm{I}-\mathrm{E}$ & \\
\hline C57BL/6 & $\mathrm{b}$ & b & $\mathrm{b}$ & $\mathrm{b}$ \\
\hline B10.A & $\mathrm{k}$ & $\mathrm{k}$ & $\mathrm{k}$ & d \\
\hline B10.S & $\mathbf{s}$ & s & s & s \\
\hline B10.P & $\mathrm{p}$ & $\mathrm{p}$ & $\mathrm{P}$ & $\mathrm{p}$ \\
\hline B10.Q & $\mathrm{q}$ & $q$ & q & $q$ \\
\hline B10.M & $\mathrm{f}$ & f & $\mathrm{f}$ & f \\
\hline B10.RIII & $r$ & $\mathrm{r}$ & $r$ & $\mathrm{r}$ \\
\hline B10.D2 & $d$ & $d$ & d & d \\
\hline$B 10 . A(4 R)$ & $\mathrm{k}$ & k & b & $\mathrm{b}$ \\
\hline$B 10 . A(3 R)$ or $(5 R)$ & $\mathrm{b}$ & b & $\mathrm{k}$ & d \\
\hline B10.MBR & $\mathrm{b}$ & k & $\mathrm{k}$ & $q$ \\
\hline B6.CH- $2^{\mathrm{bm} 12}$ & $\mathrm{~b}$ & $b^{*}$ & $\mathrm{~b}$ & b \\
\hline
\end{tabular}

Lower case letters indicate different alleles at the loci indicated.

* Site of the bm 12 mutation is the $B$ chain of the I-A molecule. . 


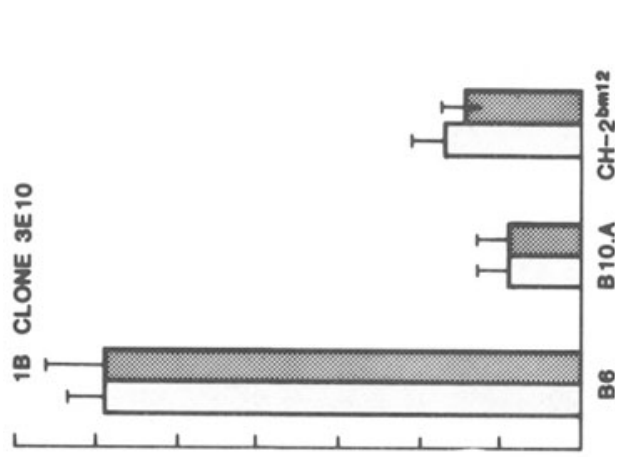

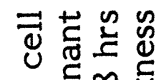
十. 氙芯䓃 出山 टृ

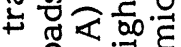

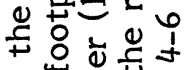

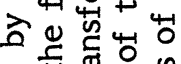

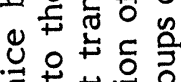

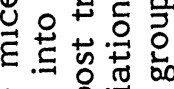

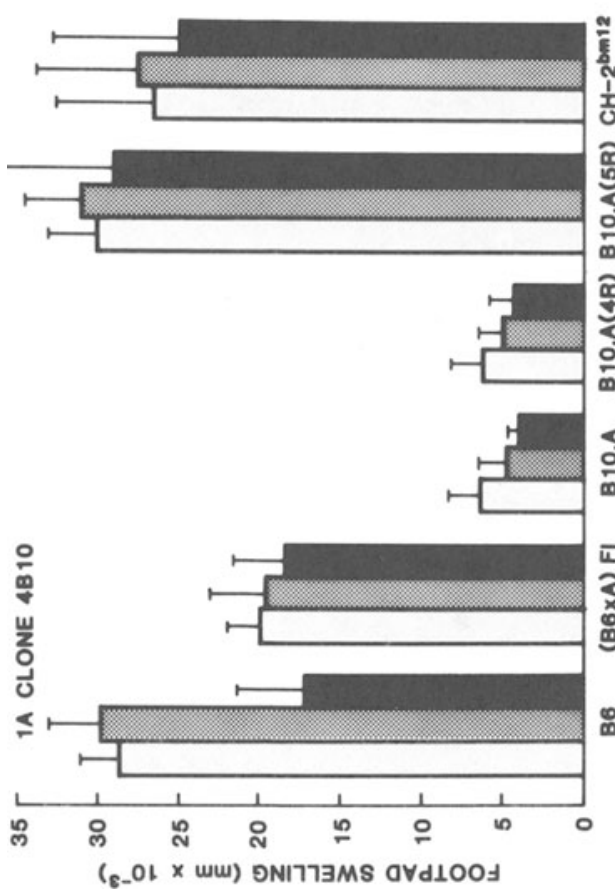
(4) ๕ ఏ.

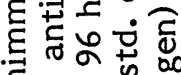

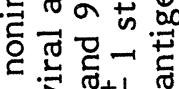
ᄃ

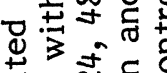
㫕苟宁 플 है 즈웡 잉 空四志岳它

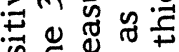

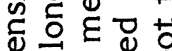
जण 0 \& 0 ปับ हैं ह ڤั 福 แ્ 음

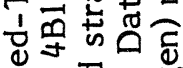

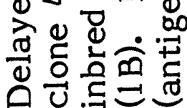


We have utilized these inbred strains as donors of APC's to determine the Ia antigens required for the in vitro response of the $4 \mathrm{~T}$ cell clones. The data in Table 3 show that none of the $T$ cell clones respond to antigen in the absense of added APC's. All clones respond quite well when B6 irradiated spleen cells as a source of APC are included along with JHMV antigen. However, none of the clones respond to JHMV antigen when presented on APC's derived from the 7 other independent haplotypes tested. These data demonstrate that the $\mathrm{T}$ cell clones show an absolute requirement for APC's and that they are genetically restricted to the $\mathrm{H}-2^{\mathrm{b}}$ haplotype.

Table 3

\section{Genetic Restriction of Antigen Presentation to JHMV-Specific T Cell Clones}

\begin{tabular}{|c|c|c|c|c|c|c|c|c|}
\hline \multirow{3}{*}{$\begin{array}{l}\text { Irradiated } \\
\text { SpleenzCells } \\
\text { Added }^{2}\end{array}$} & \multirow{2}{*}{\multicolumn{6}{|c|}{ 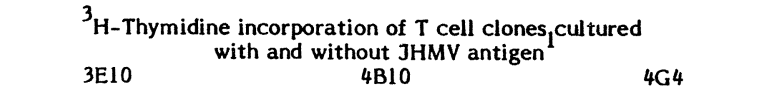 }} & \multirow{2}{*}{\multicolumn{2}{|c|}{$3 C_{4}$}} \\
\hline & & & & & & & & \\
\hline & - & + & - & + & $=$ & + & - & + \\
\hline NONE & 245 & 236 & 241 & 218 & 137 & 171 & 40 & 81 \\
\hline $\mathrm{C} 57 \mathrm{BL} / 6$ & 421 & 36,543 & 240 & 82,165 & 347 & 36,520 & 108 & 21,600 \\
\hline B10.A & 132 & 269 & 300 & 312 & 149 & 371 & 146 & 551 \\
\hline B10.S & 113 & 165 & 332 & 1,429 & 97 & 133 & 47 & 109 \\
\hline B10.P & 142 & 457 & 455 & 472 & 182 & 193 & 110 & 206 \\
\hline B10.Q & 74 & 101 & 2,609 & 6,551 & 347 & 968 & 59 & 74 \\
\hline B10.M & 49 & 47 & 256 & 251 & 174 & 413 & 58 & 95 \\
\hline BIO.RIII & 99 & 99 & 99 & 414 & 146 & 528 & 66 & 120 \\
\hline B10.D2 & 151 & 260 & 89 & 149 & 83 & 113 & 28 & 60 \\
\hline B10.A (4R) & 130 & 696 & 56 & 309 & 263 & 557 & 39 & 156 \\
\hline B10.A (3R) & 1,166 & 67,382 & 297 & 78,819 & 643 & 35,964 & 296 & 14,913 \\
\hline B10.MBR & 89 & 302 & 14 & 377 & 93 & 154 & 55 & 100 \\
\hline B6.CH-2 $2^{\mathrm{bm} 12}$ & 243 & 233 & 242 & 32,309 & 434 & 9,815 & 59 & 107 \\
\hline
\end{tabular}

1. T cell clones $\left(2 \times 10^{4} /\right.$ well) were cultured with $(+)$ or without $(-)$ JHMV antigen (1:100 dilution) for 3 days. Results represent mean counts per minute of triplicate wells.

2. 2000 Rad irradiated spleen cells $\left(4 \times 10^{5}\right.$ cells/well) from the strains indicated were added at the begining of the culture period.

In order to determine whether the clones are restricted to the I-A or the I-E molecules, APC's from the recombinant inbred strains B10.A (3R) and $B 10 . A(4 R)$ were tested. Cells from B10.A (3R) but not B10.A (4R) were able to function as APC's in this system, indicating that the relevant I region molecule involved in presenting JHMV antigen to these $\mathrm{T}$ cell clones is the I-A molecule. Additional information was gained by using APC's from bm 12 mice. This mutant strain differs from the wild type B6 only in a small region of the chain of the I-A molecule. As shown in Table 3, JHMV-specific $\mathrm{T}$ cell clone 4B10 responded well to JHMV antigen presented on bm12 APC's whereas clones $3 \mathrm{E} 10$ and $3 \mathrm{C}_{4}$ were totally 
Table 4

Antigen Specificity of $\mathrm{T}$ Cell Clones

\begin{tabular}{|c|c|c|c|c|c|}
\hline \multirow[b]{2}{*}{ T Cell Clone ${ }^{1}$} & \multicolumn{5}{|c|}{${ }^{3} \mathrm{H}$-thymidine incorporation in the presence of ${ }^{2}$ : } \\
\hline & $\begin{array}{c}\text { Control Cell } \\
\text { Lysate }\end{array}$ & JHMV & MHV-2 & MHV-A59 & $\begin{array}{r}\text { Purified } \\
\text { JHMV } \\
\end{array}$ \\
\hline $\begin{array}{l}3 \mathrm{E} 10 \\
4 \mathrm{~B} 10 \\
4 \mathrm{G} 4 \\
3 \mathrm{C} 4\end{array}$ & $\begin{array}{l}206 \\
148 \\
164 \\
708\end{array}$ & $\begin{array}{l}13,296 \\
31,986 \\
17,698 \\
\text { N.D. }\end{array}$ & $\begin{array}{l}22,185 \\
27,284 \\
18,981 \\
\text { N.D. }\end{array}$ & $\begin{array}{l}1,203 \\
7,907 \\
\text { N.D. } \\
\text { N.D. }\end{array}$ & $\begin{array}{l}22,283 \\
53,157 \\
\text { N.D. } \\
14,522\end{array}$ \\
\hline
\end{tabular}

1. T cell clones $\left(2 \times 10^{4} /\right.$ well) were cultured in the presence of syngeneic (C57BL/6) irradiated spleen cells $\left(4 \times 10^{5} /\right.$ well $)$.

2. Cultures were pulsed on day 2 and narvested on day 3. Results represent mean CPM of triplicate wells. Antigen was diluted to $1: 120$ for purified JHM and 1:60 for the rest.

gp180/90. The other monoclonals specific for the viral nucleocapsid protein pp60 and the minor envelope glycoprotein gp 25 had no effect on the proliferative response. These data suggest that the receptor on clone $3 \mathrm{E} 10$ may recognize antigenic determinants on the virion major envelope glycoprotein.

\section{DISCUSSION}

The rationale for producing JHMV-specific $\mathrm{T}$ cell clones is, in many ways, similar to the rationale for producing monoclonal antibodies. Because of the extremely fine specificity of binding, monoclonal antibodies are extremely useful for dissecting the functional and nonfunctional antigenic domains of individual proteins as well as for obtaining information on the role of humoral immunity in disease processes. In an analogous manner $\mathrm{T}$ cell clones allow the examination of the fine specificity of the antigens involved in the generation of the cell mediated immune response as well as the characterization of the individual $\mathrm{T}$ cell types participating in the immune response.

In our initial attempts to delve into the role of cellular immunity in the response to JHMV we have isolated fourteen independent. JHMV antigen specific $\mathrm{T}$ cell clones and have characterized four of them. The 
incapable of responding. Clone $4 \mathrm{G} 4$ gave a very weak response to JHMV presented on bm12 APC's. These data indicate that the bm 12 mutation eliminated the sites on the I-A molecule required for antigen presentation to clones $3 \mathrm{E} 10$ and $3 \mathrm{C} 4$ but not for clone 4B10. Since the mutation in $\mathrm{bm} 12$ is in the $\beta$ chain, these data suggest that clones $3 \mathrm{E} 10$ and $3 \mathrm{C} 4$ recognize JHMV antigen at least in part in association with the $\beta$ chain whereas clone $4 \mathrm{~B} 10$ recognizes JHMV antigen predominately in association with the $\alpha$ chain. Clone $4 \mathrm{G} 4$ may utilize a portion of the determinant affected by the bm 12 mutation.

In vivo Genetic Restriction: Experiments were conducted to determine whether these JHMV-specific $\mathrm{T}$ cell clones could mediate a delayed type hypersensitivity (DTH) response in vivo. $\mathrm{T}$ cell clones in combination with either JHMV (right foot) or control antigen (left foot) were injected into the hind footpads of mice. The data in Figure la show that Clone $4 \mathrm{~B} 10$ is capable of inducing a DTH response to JHMV only when the host shares the I-A subregion with B6. Thus, the same pattern of genetic restriction holds for the in vivo DTH response as is observed in the in vitro proliferative response. The data in Figure $1 \mathrm{~b}$ show a similar result for clone 3E10. Furthermore, in agreement with the in vitro data in Table 3, clone 4B10 gives a positive DTH response in bm12 mice whereas $3 \mathrm{E} 10$ does not. Thus the in vitro proliferative response appears to accurately reflect the in vivo DTH response in terms of the genetic restriction of the $\mathrm{T}$ cell-APC interaction.

Antigen Specificity: It was important to determine whether these $T$ cell clones were indeed specific for JHMV antigen. In preliminary experiments the $\mathrm{T}$ cell clones were re-titered with JHMV antigen and found to give optimal proliferation with dilutions of 1:60 to 1:100 (data not shown). The results in Table 4 show that all four clones proliferate in the presence of JHMV antigen and not with control antigen. In addition, three of these clones tested showed equivalent reponses when cultured with antigen prepared from MHV-2 infected cells. Two out of 2 clones tested also showed cross reaction with MHV-A59 antigen although considerably less than to JHMV or MHV-2. This is interesting in light of the fact that serologically, JHMV is more related to MHV-A59 than MHV-2. Finally, in order to rule out the possibility that the clones were responding to some cellular component or contaminant, JHMV was purified by sucrose gradient centrifugation and tested as an antigen. This preparation was in fact more effective at stimulating the clones and had a higher titer in dose response curves (data not shown).

The proliferative response to purified virus also indicated that the $T$ cell clones recognize a virus structural protein and therefore monoclonal antibodies specific for these proteins were tested for their ability to inhibit proliferation. Figure 2 shows that the proliferation of three of the four clones was not inhibited by the presence of any of the anti-viral monoclonal antibodies. Clone 3E10, however, was inhibited by all three monoclonals tested which are specific for the envelope glycoprotein 


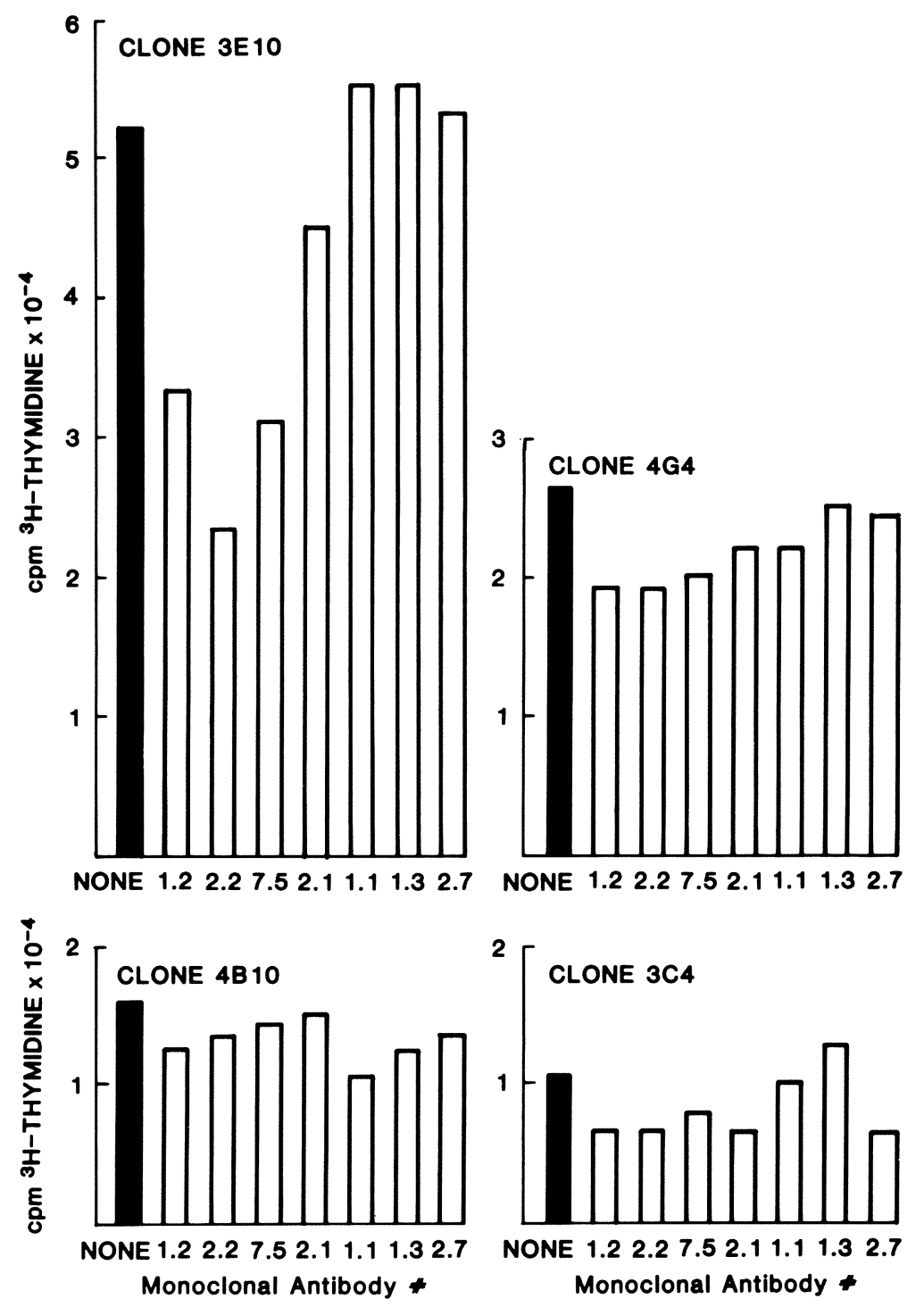

Figure 2

Inhibition of $T$ cell clone proliferation by antigen-specific monoclonal antibody. $T$ cell clones were cultured in the presence of antigen presenting cells, semi-purified IL-2, antigen, and monoclonal antibodies specific for viral antigens gp1 80 (monoclonals \# 1.2, 2.2, and 2.7), pp60 (monoclonals \# 2.1 and 1.1) and gp25 (monoclonals \# 1.3 and 2.7). ${ }^{3} \mathrm{H}$-thymidine incorporation was determined at 3 days. 
four clones all bear the classical "T helper cell" surface phenotype and exhibit an absolute requirement for both antigen presenting cells and the eliciting antigen. They also demonstrate a strict genetic restriction in that only APC's bearing I-A region gene products of the $\mathrm{H}-2{ }^{\mathrm{D}}$ haplotype function in the presentation of antigen to the $T$ cell clones which were derived from the $\mathrm{H}-2^{\mathrm{b}} \mathrm{C}$ 57BL/6 strain. In addition we have shown that the in vivo response is genetically restricted to the $\mathrm{H}-2^{\mathrm{D}} \mathrm{I}-\mathrm{A}$ haplotype expressed on the endogenous APC's which is exactly analogous to the in vitro data presented. Finally, since the utility of the $T$ cell clones would ultimately reside in their ability to remain functional in an in vivo setting we have shown that the four clones are capable of eliciting a delayed type hypersensitivity response.

The differential ability of the four $\mathrm{T}$ cell clones to recognize JHMV antigen in combination with the mutant la molecule expressed on the APC's derived from the $\mathrm{B} 6 \mathrm{CH}-2^{\mathrm{dm} 12}$ mouse provides an indication that at least three of the four clones are distinct in terms of Ia receptor specificity. $\mathrm{T}$ cell clones $3 \mathrm{E} 10$ and $3 \mathrm{C} 4$ must have a receptor that recggnizes the virus antigen in combination with a different portion of the $\mathrm{I}-\mathrm{A}$ molecule than the $4 \mathrm{~B} 10$ clone since the former clpne cannot recognize JHMV antigen in combination with the mutant $I-A$ while the latter clone does. The receptor on clone 4G4 probably represents a third distinct recognition site since it responds partially to JHMV antigen presented on bm12 APC's. This fine specificity of $\mathrm{T}$ cell clones to recognize determinants on the Ia molecule in conjunction with antigen was first demonstrated by Kimoto and Fathman (1980) and appears to be a general property of helper $\mathrm{T}$ cell clones which all show genetic restriction to the Ia molecule.

The ability of our $\mathrm{T}$ cell clones to induce a DTH reaction correlates well with results from other labs using various $T$ cell-antigen combinations (Bianchi, et al, 1981; Weiss and Dennert, 1981). A large body of evidence has accumulated concerning the mechanism of this response. Antigen injected into the footpad becomes rapidly bound to Ia bearing APC's, either tissue macrophages, dendritic cells or Langerhans cells. Since the $T$ cell clones are injected into the same site as antigen, specific Ia restricted recognition occurs resulting in proliferation and lymphokine release by the $T$ cells. The lymphokine release results primarily in the infil tration of monocytes resulting in a demonstrable DTH type reaction.

The other facet of the signal required for a $\mathrm{T}$ cell proliferative response is the particular JHMV antigen recognized in combination with the Ia molecule. We have initiated three experimental avenues to examine this question. The first was to use antigens prepared from serologically distinct strains of MHV. The antigen prepared from MHV-A59 infected cells was able to stimulate some proliferation in the two clones tested. The antigen prepared from MHV-2 infected cells was recognized as efficiently as JHMV antigen, indicating that the antigenic domain recognized by the $\mathrm{T}$ cell clones is very conserved in MHV-2 and 
was less conserved in MHV-A59. The second avenue was to test the ability of gradient purified virus to be recognized by the $\mathrm{T}$ cell clones. All three clones tested responded to purified virus. This information indicates that the $\mathrm{T}$ cell clones are responding to virus structural proteins or a derivitivae of these produced by antigen processing and not to virus-specified nonstructural proteins found in the cell lysate used as an antigen.

These data therefore indicate that the proliferation induced by MHV-2 is induced by cross-reactive antigenic determinants on a virus structural protein. To examine the relative conservation of the viral proteins, a panel of monoclonal antibodies specific for the JHMV virion proteins was tested for their ability to bind to other MHV strains. These data show that the pp60 and gp 25 proteins are relatively conserved, while the envelope glycoprotein gp 180/90 is relatively unique. This finding led to our third approach to defining the viral antigen recognized in association with Ia. $T$ cell proliferation assays were carried out in the presence of a number of monoclonal antibodies specific for the virus structural protein. The proliferation of three of the $T$ cell clones was not inhibited by any of the monoclonal antibodies tested. Clone 3E10, however, was inhibited by three monoclonals (J1.2, J2.2, and J7.5) all directed against the gp180/90 envelope glycoprotein. Neither the monoclonal antibodies directed against pp60 (J2.1 and 1.1) nor those reactive with the minor envelope glycoprotein gp25 (J1.3 and 2.7) inhibited proliferation. Although the proliferative response was not completely inhibited, these data indicate that $\mathrm{T}$ cell clone $3 \mathrm{E} 10$ recognized the virion major envelope glycoprotein in association with Ia.

This work is only beginning and a large number of questions remain. We have shown that the helper $T$ cell clones we have isolated have retained some aspects of their ability to function in vivo. The role of the various subpopulations of $T$ cells during JHMV infection remains to be elucidated but these clones will allow a unique possibility to examine directly the role of a specific $T$ cell population in protection from acute viral encephalomyelitis and give insight into the delicate balance between completely clearing an infection and the establishment of chronic disease. It should also be possible, either by directly inhibiting proliferation or by using immunoaffinity columns, to define the viral antigens recognized in conjunction with Ia for the stimulation of the helper $T$ cell population.

\section{ACKNOWLEDGEMENTS}

This work was supported by grant NS 18146 from the National Institutes of Health. J.A.F. is the recipient of an American Cancer Society Faculty Research Award. The authors wish to express their gratitude to Raymond L. Mitchell for editorial assistance. 


\section{REFERENCES}

- Bailey, O.T., Pappenheimer, A.M., Cheever, F.S., and Daniels, J.B. (1949). A murine virus (JHMV) causing disseminated encephalomyelitis with extensive destruction of myelin. II. Pathology. J. Exp. Med. 90:195-212.

- Bianchi, A.T., Hooijkass, H., Benner, R., Tees, R., Nordin, A., and Schreier, M. (1981). Clones of helper $T$ cells mediate antigen-specific, H-2 restricted DTH. Nature 290:62-63.

- Fleming, J., Stohlman, S., Harmon, R., Lai, M., Frelinger, J., and Weiner, L. (1983). Antigenic relationship of murine coronaviruses: Anaylsis using monoclonal antibodies to JHM (MHV-4) virus. Virology in press.

- Herndon, R.M., Griffin, D.E., McCormick, U., and Weiner, L.P. (1975). Mouse hepatitis virus-induced recurrent demyelination. Arch. Neurol. 32:32-35.

- Kimoto, M., and Fathman, C.G. (1980). antigen reactive T cell clones. I. Transcomplementing hybrid I-A-region gene products function effectively in antigen presentation. J. Exp. Med. 152:759-769.

- Lai, M.M.C., and Stohlman, S.A. (1978). The RNA of mouse hepatitis virus. J. Virol. 26:236-242.

- Stohlman, S.A., and Frelinger, J.A. (1978). Resistance to fatal central nervous system disease by mouse hepatitis virus strain JHM. I. Genetic Analysis. Immunogenetics. 6:277-281.

- Stohlman, S.A., and Weiner, L.P. (1978). Stability of neurotropic mouse hepatitis virus (JHM strain) during chronic infection of neuroblastoma cells. Arch. Virol. 57:53-61.

- Stohlman, S.A., and Weiner, L.P. (1981). Chronic central nervous system demyelination in mice after JHM virus infection. Neurol. 31:38-44.

- Stohlman, S.A., Brayton, P.R., Fleming, J.O., Weiner, L.P., and Lai, M.M.C. (1982). Murine coronaviruses: Isolation and characterization of two plaque morphology variants of the JHM neurotropic strain. J. Gen. Virology 63:265-275.

- Swain, S.L., Dennert, G.L., Wormsley, S., and Dutton, R.L. (1981). The Lyt phenotype of a long-term allospecific $T$ cell line. Eur. J. Immunol. 11:175-180.

- Wege, H. Siddell, S. and ter Meulen, V. (1982). The biology and pathogenesis of coronaviruses. Curr. Tpics Microbiol. Immunol. 99:165-200.

- Weiss, S., and Dennert, G. (1981). T cell lines active in the DTH reaction. J. Immunol. 126:2031-2035.

- Yano, A., Schwartz, K.W. and Paul, W.E. (1977). Antigen presentation in the murine $\mathrm{T}$ lymphocyte proliferative response. I. Requriement for genetic identity at the major MHC. J. Exp. Med. $146: 828-842$. 